\title{
Characteristics and Behavior of Transient Current during Multiple Lightning strokes on a Train in Thailand by using ATPDraw
}

\author{
Kelvin Melckzedeck Minja, Pius Victor Chombo, Narupon Promvichai, Uthen Leeton, Boonruang Marungsri* \\ School of Electrical Engineering, Suranaree University of Technology \\ 111 University Avenue, Muang District, Nakhon Ratchasima 30000, Thailand. \\ *Corresponding Author: bmshvee@sut.ac.th
}

\begin{abstract}
This study describes characteristics and behavior of transient current during Multiple lightning strokes on train's pantograph of $2 \times 25 \mathrm{kV}$ AC, $50 \mathrm{~Hz}$ Catenary Contact System. $25 \mathrm{kV}$ AC, $50 \mathrm{~Hz}$ Catenary Contact System on double-track elevated railway system which connects Suvarnabhumi Airport to central Bangkok (Phayathai, Makkasan) was used in the study. The characteristics of transient current in term of its magnitude, front times and tail times affected by Multiple lightning strokes were studied. The assumption of studies based on the return Multiple lightning strokes current ranging 1-200 kA, front time of multiple lightning strokes between $1-3 \mu \mathrm{s}$, elevated pole resistance of $50 \Omega$ and grounding resistance of $5 \Omega$. The Behaviour of transient current when the pantograph is at the Mast ( $4^{\text {th }}$ Mast) for Case 1 and at the mid-span of Masts ( $3^{\text {rd }}$ and $4^{\text {th }}$ Masts) for Case 2 were also studied. The Catenary Contact System on elevated railway system with a train and multiple lightning strokes were modeled in ATPDraw software. Transient current of negative multiple lightning strokes showed flashovers across insulators in any magnitude and waveform for Case 1 and Case 2. The improved protection for Catenary Contact System should consider the effects of negative multiple lightning strokes.
\end{abstract}

Keywords: Catenary, Elevated pole, Multiple lightning strokes, Flashover, ATPDraw.

\section{Introduction}

Until recently, Catenary Contact System has been the most traction power supply system to deliver power to electric train ${ }^{(1-2)}$. However, most of the overhead catenary transmission lines suffer from the lightning problems ${ }^{(2-3)}$.
Lightning strokes are the major source of transient current with random characteristics and behavior which may lead to power system failure ${ }^{(3-5)}$. The overvoltage due to transient current during lightning strokes was shown to be mostly likely caused by a stroke to phase conductor, shielding wire, and ground in line proximity ${ }^{(3,6)}$. But the stability of power system can be more affected when lightning strikes on conductors ${ }^{(6-7)}$. Flashover occurs when the induced overvoltage exceeds lightning withstand voltage level of insulators ${ }^{(2)}$. Current research studies have explained lightning effects when strikes in the Overhead Catenary Transmission line $e^{(1,3,8-13)}$.

Thailand is among of tropical countries which experience thunderstorm days and lightning activities per year. The report of lightning statistics in Thailand from Marungsri et al. ${ }^{(14)}$ showed that lightning often occurs in April-May but severely in June. The magnitude of 11-171 kA with positive polarity and -10 to $-139 \mathrm{kA}$ with negative polarity were reported. Positive lightning strokes were accounted for $5 \%$ while negative were $95 \%$ with the magnitude of -10 to $-50 \mathrm{kA}$. Negative lighting was showed to have a higher possibility of a multiplicity of strokes per flash $^{(15-18)}$. Most of the studies in the overhead catenary system have been examined the effects of lightning strikes on the mast, conductors, and traction substation by using several transient programs for simulation ${ }^{(1,3,8-12)}$. These studies have been done on single lightning strokes without considering the effects of multiple lightning strokes. Despite the fact that the lightning protection was studied, but it is important to understand the variation of transient current behavior during multiple lightning strokes in different waveforms while doing lightning protection analysis.

In this paper, characteristic of transient current in a 25 
$\mathrm{kV}$ Overhead Catenary transmission line is presented by using ATPDraw software. The behaviors of peak current, when negative multiple lightning strokes strike on pantograph are investigated.

\section{Background}

The examined system uses overhead catenary transmission line on elevated railway system which is designed with catenary wire, return wire and auxiliary wire as indicated in Fig. 1. The supply voltage of the system is $25 \mathrm{kV} \mathrm{AC}-50 \mathrm{~Hz}$ as per IEC 60850:2014 ${ }^{(19)}$. An overhead catenary transmission line of $480 \mathrm{~m}$ length supported by 7 masts with $60 \mathrm{~m}$ spacing was selected for simulation. The supply voltage was applied on both end points of the line. Since lightning behavior is unpredictable, the strike on pantograph as part of the conductor was mostly considered. Case 1 was considered the strike on pantograph at the $4^{\text {th }}$ Mast (see Fig. 1(a)) and Case 2 between the $3^{\text {rd }}$ and $4^{\text {th }}$ Masts (see Fig. 1(b)). The magnitudes of $-34 \mathrm{kA},-50 \mathrm{kA}$, and $-100 \mathrm{kA}$ with $1 / 30.2 \mu \mathrm{s}, 1.2 / 50 \mu \mathrm{s}, 2 / 77.5 \mu \mathrm{s}$ and $3 / 75$ $\mu$ s waveforms were used as lightning sources $^{(14)}$. The elevated poles and grounding resistances were assumed to be $50 \Omega$ and $5 \Omega$ respectively.

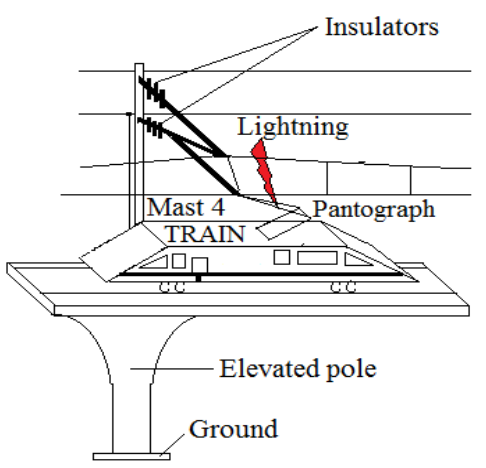

(a) at the Mast.

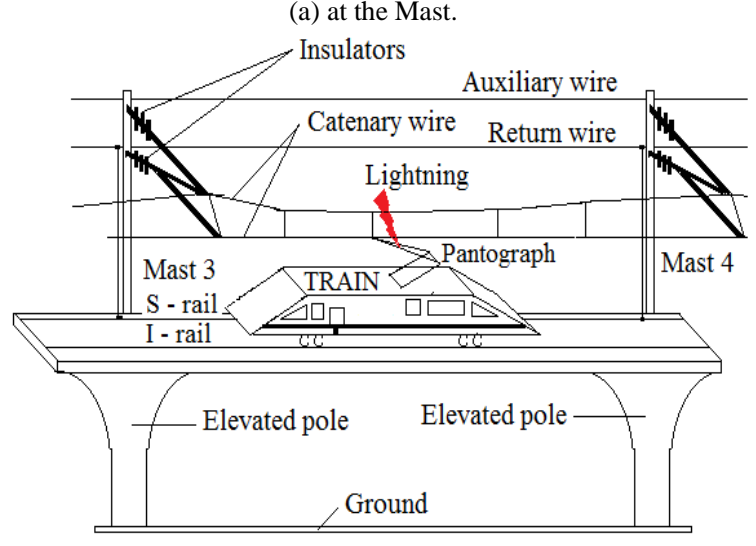

(b) at the mid-span of Masts.

Fig. 1. Lightning strike on train's pantograph.

\section{Modeling of Catenary Contact System}

\subsection{Overhead Catenary Transmission line}

The details of Overhead Catenary Transmission line involved Catenary line (R1), return line (R2), Auxiliary line (R3) with running rails (S-rail, I-rail) and distributed-parameter line spans on both sides of the impact point were given Table $1^{(12)}$. A Railway Transmission line was modeled by LCC_8 with JMARTI model in ATPDraw as shown in Fig. 2. Catenary line, return line, Auxiliary line includes S-rail and I-rail were considered in this study as in Mazloom $^{(12)}$; Achouri, Achouri, and Khamliche ${ }^{(8)}$ with Autotransformer and Booster transformer as modeled by 1:1 ideal transformers in ATPDraw. Yang and Zhang ${ }^{(9)}$ showed that Autotransformer and Booster transformer force the traction current to return through designated return conductors to traction supply. Also, it reduces stray current which may cause electromagnetic interference with electrical systems in the vicinity of the railway system. Mast configuration parameters of $2 \times 25 \mathrm{kV} \mathrm{AC}, 50 \mathrm{~Hz}$ Catenary Contact System are given in Table $2^{(13)}$.

Table 1. Details of $25 \mathrm{kV}$ Overhead Catenary Transmission Line ${ }^{(12)}$.

\begin{tabular}{|c|c|c|c|c|c|}
\hline \multicolumn{6}{|c|}{ Overhead Catenary Transmission line } \\
\hline Conductors & Catenary & Return & Auxiliary & S-rail & I-rail \\
\hline Radius $(\mathrm{cm})$ & 5.06 & 0.82 & 0.56 & 4.95 & 4.95 \\
\hline \multirow{2}{*}{ Ruling Span } & \multicolumn{5}{|c|}{ Between Masts (m) } \\
\hline & \multicolumn{5}{|c|}{60} \\
\hline \multirow{2}{*}{$\begin{array}{c}\text { Earthing } \\
\text { Resistance }\end{array}$} & \multicolumn{2}{|c|}{ Grounding $(\Omega)$} & \multicolumn{3}{|c|}{ Elevated Pole $(\Omega)$} \\
\hline & \multicolumn{2}{|c|}{5} & \multicolumn{3}{|c|}{50} \\
\hline \multicolumn{6}{|c|}{ Insulators (Impulse Withstand Voltage) } \\
\hline \multicolumn{2}{|c|}{ Rod/Composite (R1) } & \multicolumn{2}{|c|}{ Spool (R2) } & \multicolumn{2}{|c|}{ Pin (R3) } \\
\hline \multicolumn{2}{|c|}{$225 \mathrm{kV}$} & \multicolumn{2}{|c|}{$60 \mathrm{kV}$} & \multicolumn{2}{|c|}{$140 \mathrm{kV}$} \\
\hline
\end{tabular}

Table 2. Mast Configuration ${ }^{(13)}$.

\begin{tabular}{|c|c|c|c|c|c|}
\hline \multicolumn{5}{|c|}{ Parameters } \\
\hline $\mathrm{h}_{1}(\mathrm{~m})$ & $\mathrm{h}_{2}(\mathrm{~m})$ & $\mathrm{h}_{3}(\mathrm{~m})$ & $\mathrm{h}_{4}(\mathrm{~m})$ & $\mathrm{h}_{5}(\mathrm{~m})$ & $\mathrm{h}_{6}(\mathrm{~m})$ \\
\hline 8 & 6.55 & 5.5 & 5.3 & 0.96 & 0.96 \\
\hline $\mathrm{r}_{1}(\mathrm{~m})$ & $\mathrm{r}_{2}(\mathrm{~m})$ & $\mathrm{r}_{3}(\mathrm{~m})$ & $\mathrm{r}_{4}(\mathrm{~m})$ & $\mathrm{r}_{5}(\mathrm{~m})$ & $\mathrm{r}_{6}(\mathrm{~m})$ \\
\hline 1.12 & 2.5 & 0.12 & 2.5 & 1.74 & 3.26 \\
\hline
\end{tabular}




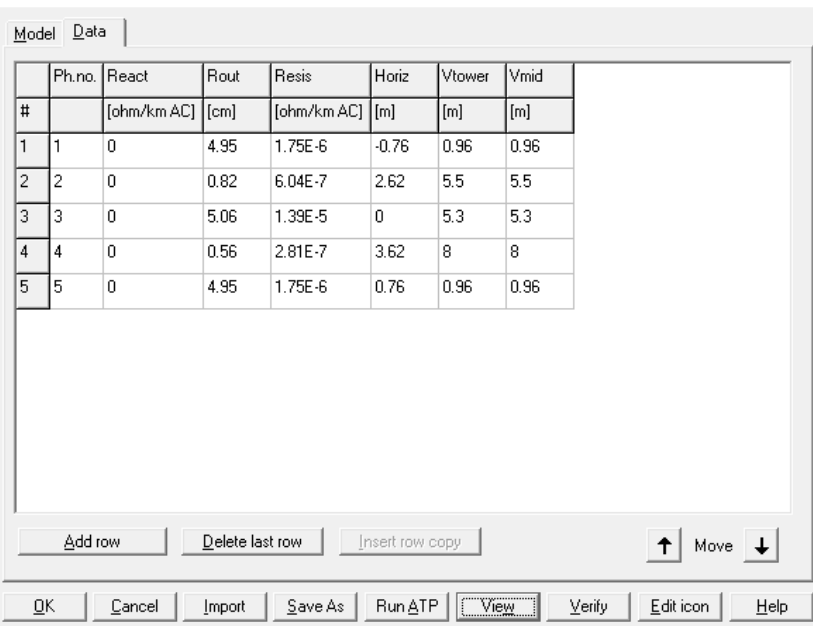

Fig. 2. Transmission line data in ATPDraw.

\subsection{Multiple Lightning Source Model}

Negative lightning stroke with magnitudes of -10 to $-50 \mathrm{kA}$, its association with multiple strokes per flash averaging 3 to 4 strokes per flash with intervals of tens of milliseconds were the most reported lightning incidences in Marungsri et al. ${ }^{(14)}$; Omidiora and Lehtonen ${ }^{(15,17)}$; Martinez-Velasco and Aranda ${ }^{(16)}$; Rodriguez-Sanabria, Ramos-Robles, and Orama-Exclusa ${ }^{(18)}$. Three strokes per flash were used with intervals of $1 \mathrm{~ms}$. The $1^{\text {st }}$ stroke was modeled with Heidler ideal source, the $2^{\text {nd }}$ and $3^{\text {rd }}$ strokes were modeled with two slope Ramp Type 13 in ATPDraw based on the characteristic of the lightning strokes. Parameters of lightning sources are given in Table 3, and the waveform of the multiple strokes is shown in Fig. 3.

Table 3. Parameters of multiple lightning sources ${ }^{(14-18)}$.

\begin{tabular}{|c|c|c|c|}
\hline Parameters & Source 1 & Source 2 & Source 3 \\
\hline Type & Heidler 15 & Ramp 13 & Ramp 13 \\
\hline $\begin{array}{c}\text { Multiple } \\
\text { lightning } \\
\text { sources. (kA) }\end{array}$ & -34 & -26 & -23 \\
\cline { 2 - 4 } & -50 & -42 & -39 \\
\hline To & 0 & -92 & -89 \\
\hline A1 & 0 & 0 & 0 \\
\hline T1 (sec) & 0 & 0.0003 & 0.0003 \\
\hline TSta (sec) & 0 & 0.0016 & 0.0029 \\
\hline TSto (sec) & 0.0006 & 0.0019 & 0.0032 \\
\hline
\end{tabular}

Three ideal sources were used for the multiple lightning stroke current, with time duration of $0.6 \mathrm{~ms}$ for $1^{\text {st }}$ stroke and $0.3 \mathrm{~ms}$ for $2^{\text {nd }}$ and $3^{\text {rd }}$ strokes each.

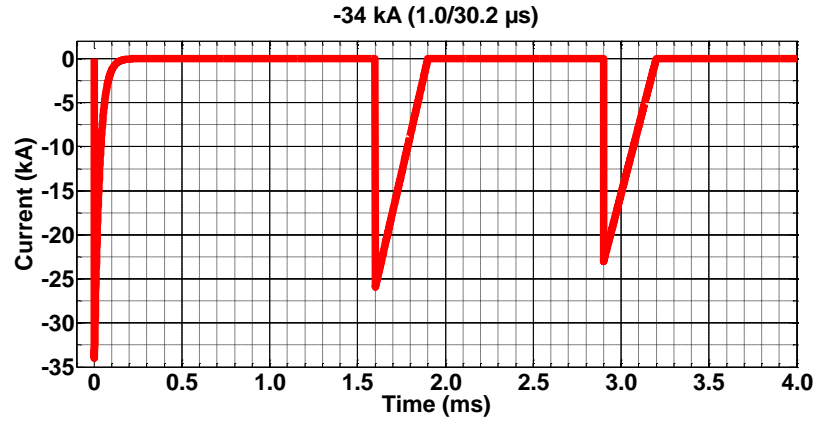

Fig. 3. Waveforms of the $1^{\text {st }}, 2^{\text {nd }}$ and $3^{\text {rd }}$ lightning of $-34 \mathrm{kA}(1.0 / 30.2 \mu \mathrm{s})$ strokes modeled in ATP EMTP.

\subsection{Mast Model}

The mast was modeled by cylindrical geometrical steel column in single wave impedance model as recommended by IEEE and CIGRE in expression $(1)^{(9,20)}$. The modeled parameters of the mast are shown in Table 4.

$$
Z=60 \operatorname{In} \cot \left[0.5 \arctan \left(\frac{R}{H}\right)\right]
$$

Table 4. Modeled Parameters of Mast.

\begin{tabular}{|l|l|}
\hline Location & Parameters \\
\hline Auxiliary & Zaux $=157.64 \Omega, \mathrm{L} 1=2.5 \mathrm{~m}$ \\
\hline Return & Zreturn $=293.57 \Omega, \mathrm{L} 2=0.2 \mathrm{~m}$ \\
\hline Catenary & Zcatenary $=113.77 \Omega, \mathrm{L} 3=5.3 \mathrm{~m}$ \\
\hline
\end{tabular}

\subsection{Train Model}

The three-car train was modeled as electric locomotive which contains Pantograph, Locomotive transformer, Diode rectifier bridge and two DC motors as in Zupan, Teklić, and Filipović-Grčić( ${ }^{(21)}$; KaragÖz ${ }^{(22)}$. Figs. 4 shows the model of Train contains Pantograph, Locomotive transformer, Diode rectifier bridge and one DC motor with Railway Transmission line, Mast, Elevated pole, Ground and Insulators at the Mast and at the mid-span of Masts. Insulators of Mast were modeled with a branch of capacitor and voltage controlled switch as shown in Fig. 4(a). To model this insulator, Switchvc.sup model was used in ATPDraw with voltage withstand capability as calculated values given in Table $1^{(23)}$. 


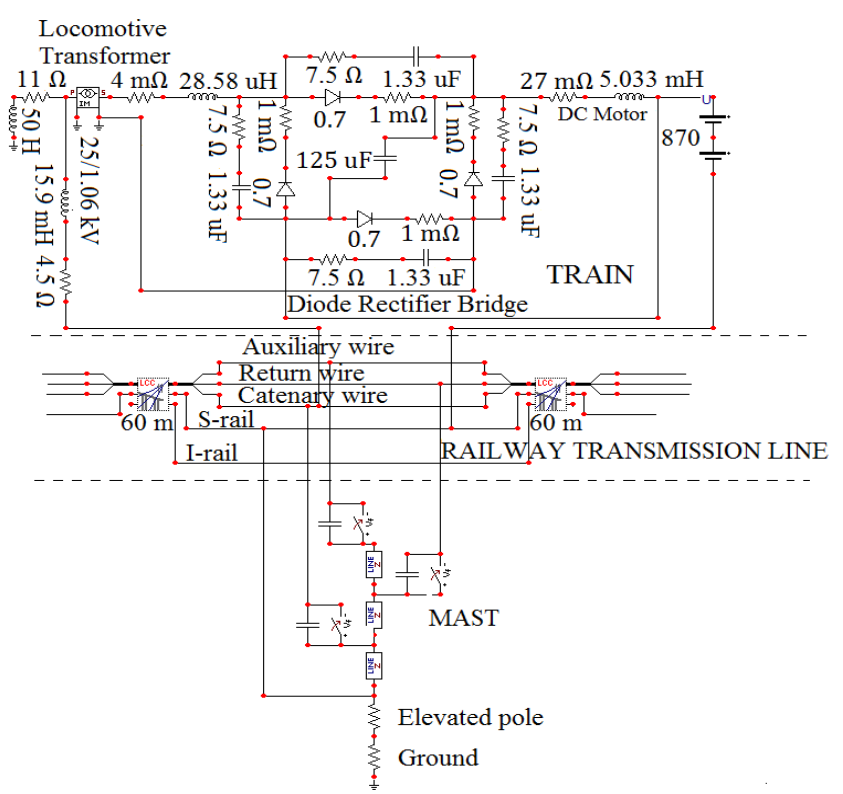

(a) At the Mast.

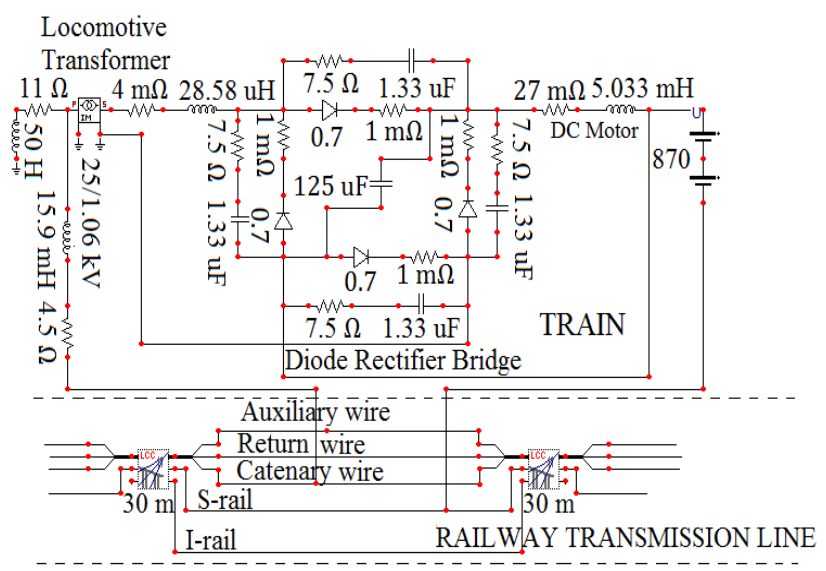

(b) At the mid-span of Masts.

Fig. 4. Train modeled in ATPDraw.

\section{Simulation Results}

A $25 \mathrm{kV}$ Railway Transmission line with 7 masts in Case 1 and Case 2 were simulated in ATPDraw with multiple lightning sources on the pantograph where elevated poles and grounding resistance were set to $50 \Omega$ and $5 \Omega$ unchanged respectively. The magnitude, front time and tail time of negative multiple lightning strokes were studied as factors that cause a transient current which leads flashover across insulators.

As the impulse voltage withstand capability of insulator depends on the front time of lightning stroke current, the multiple lightning stroke current of $-34 \mathrm{kA}$ with $1 / 30.2 \mu \mathrm{s}, 1.2 / 50 \mu \mathrm{s}, 2 / 77.5 \mu \mathrm{s}$ and $3 / 75 \mu \mathrm{s}$ was first used in the simulation. The lightning induced voltages across the insulators of the Mast 4 in Auxiliary, Return, and Catenary lines are shown in Fig. 5, 6, 7, and 8. Results of lightning induced voltages across the insulators with the magnitude of -50 and $-100 \mathrm{kA}$ in Auxiliary, Return and Catenary lines at $1 / 30.2 \mu \mathrm{s}, 1.2 / 50 \mu \mathrm{s}, 2 / 77.5 \mu \mathrm{s}$ and $3 / 75 \mu \mathrm{s}$ waveforms are shown in Fig. 9, 10, 11, 12, 13, 14, 15 and 16.

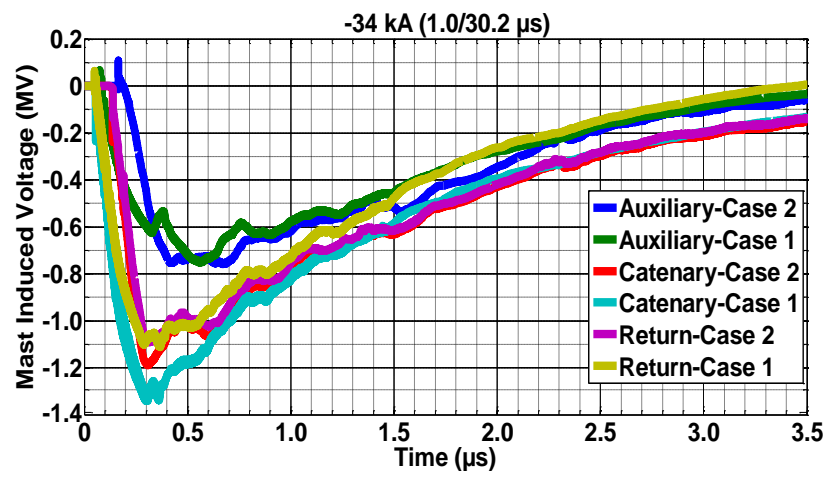

Fig. 5. Mast Induced Voltage Waveform of the $1^{\text {st }}, 2^{\text {nd }}$ and $3^{\text {rd }}$ lightning current of $-34 \mathrm{kA}(1.0 / 30.2 \mu \mathrm{s})$ strokes.

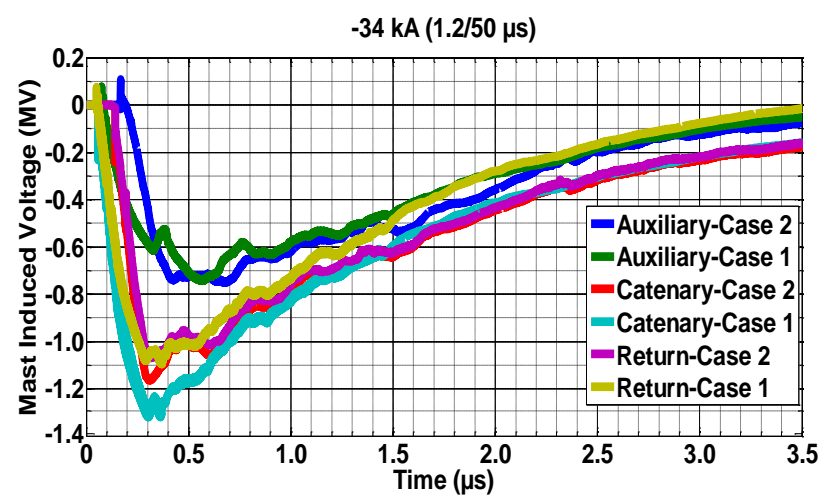

Fig. 6. Mast Induced Voltage Waveform of the $1^{\text {st }}, 2^{\text {nd }}$ and $3^{\text {rd }}$ lightning current of $-34 \mathrm{kA}(1.2 / 50 \mu \mathrm{s})$ strokes.

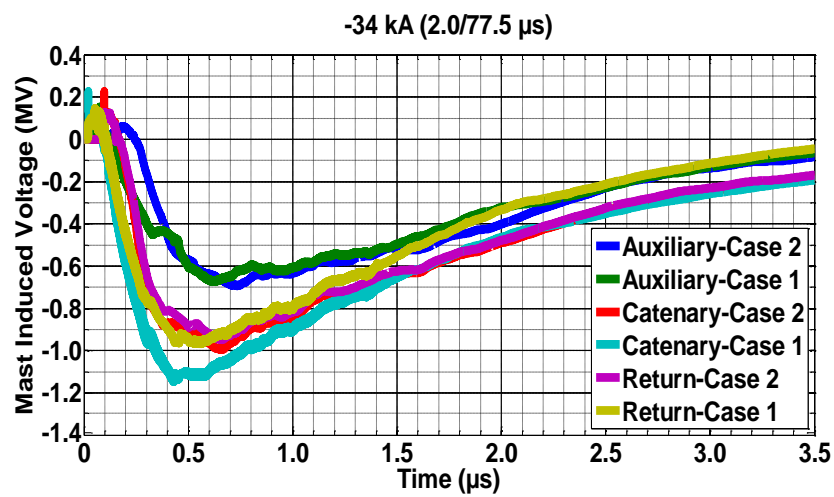

Fig. 7. Mast Induced Voltage Waveform of the $1^{\text {st }}, 2^{\text {nd }}$ and $3^{\text {rd }}$ lightning current of $-34 \mathrm{kA}(2 / 77.5 \mu \mathrm{s})$ strokes. 


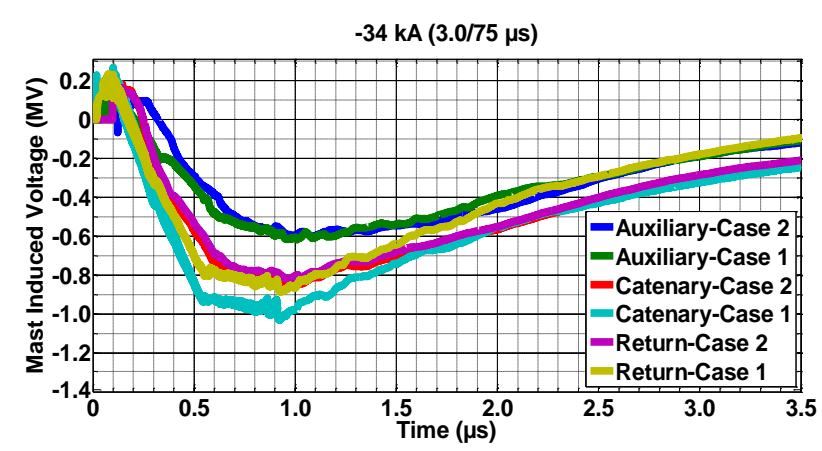

Fig. 8. Mast Induced Voltage Waveform of the $1^{\text {st }}, 2^{\text {nd }}$ and $3^{\text {rd }}$ lightning current of $-34 \mathrm{kA}(3 / 75 \mu \mathrm{s})$ strokes.

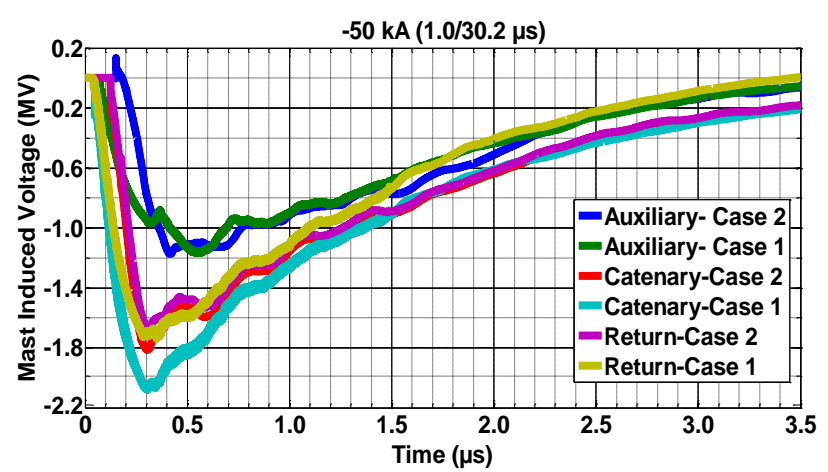

Fig. 9. Mast Induced Voltage Waveform of the $1^{\text {st }}, 2^{\text {nd }}$ and $3^{\text {rd }}$ lightning current of $-50 \mathrm{kA}(1.0 / 30.2 \mu \mathrm{s})$ strokes.

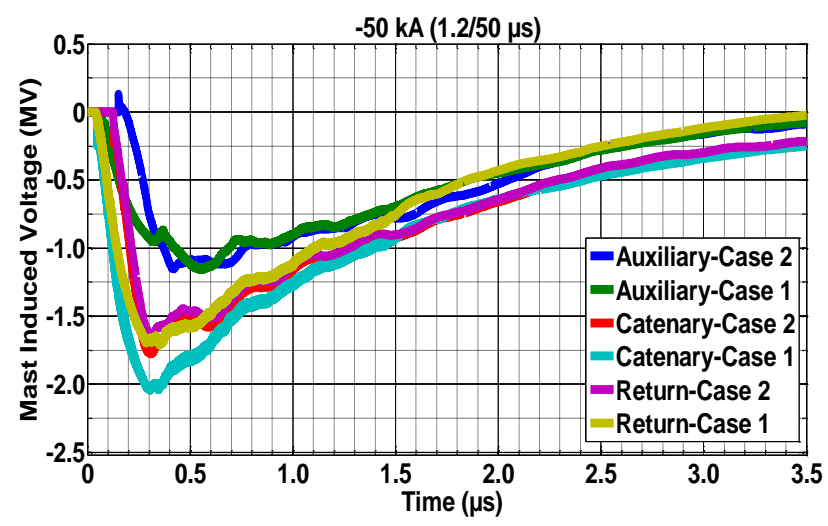

Fig. 10. Mast Induced Voltage Waveform of the $1^{\text {st }}, 2^{\text {nd }}$ and $3^{\text {rd }}$ lightning current of $-50 \mathrm{kA}(1.2 / 50 \mu \mathrm{s})$ strokes.

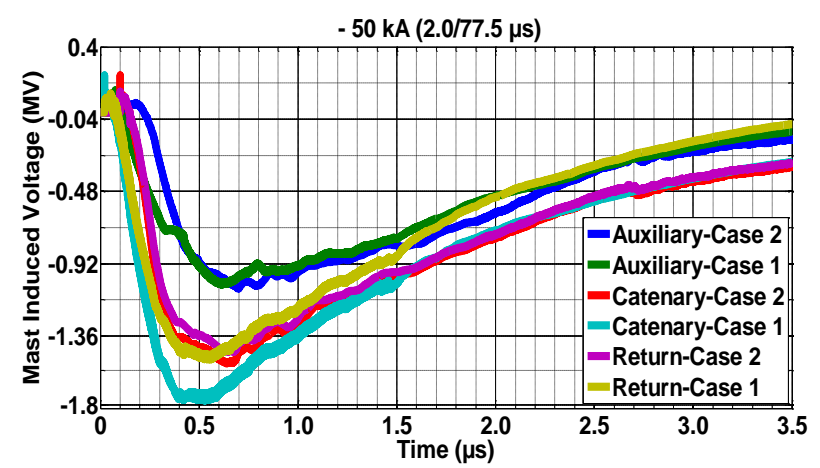

Fig. 11. Mast Induced Voltage Waveform of the $1^{\text {st }}, 2^{\text {nd }}$ and $3^{\text {rd }}$ lightning current of $-50 \mathrm{kA}(2.0 / 77.5 \mu \mathrm{s})$ strokes.

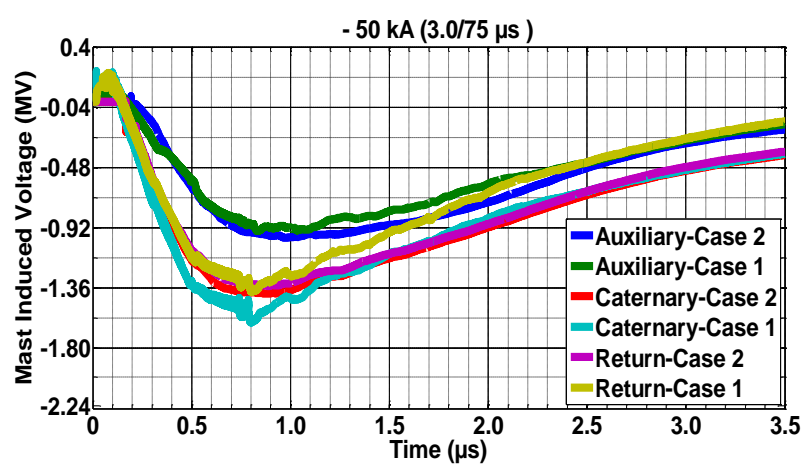

Fig. 12. Mast Induced Voltage Waveform of the $1^{\text {st }}, 2^{\text {nd }}$ and $3^{\text {rd }}$ lightning current of $-50 \mathrm{kA}(3.0 / 75 \mu \mathrm{s})$ strokes.

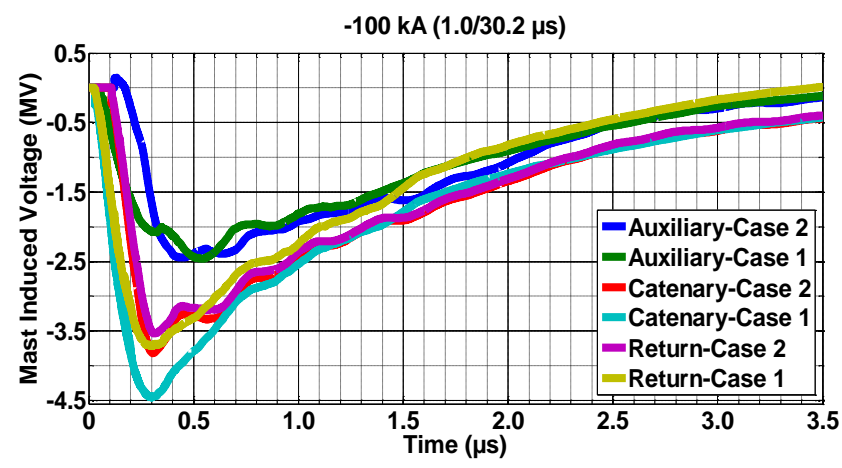

Fig. 13. Mast Induced Voltage Waveform of the $1^{\text {st }}, 2^{\text {nd }}$ and $3^{\text {rd }}$ lightning current of $-100 \mathrm{kA}(1.0 / 30.2 \mu \mathrm{s})$ strokes.

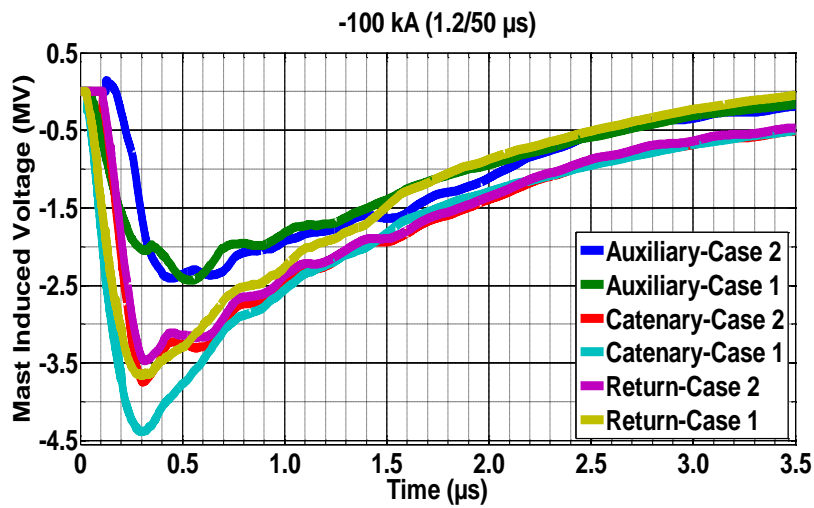

Fig. 14. Mast Induced Voltage Waveform of the $1^{\text {st }}, 2^{\text {nd }}$ and $3^{\text {rd }}$ lightning current of $-100 \mathrm{kA}(1.2 / 50 \mu \mathrm{s})$ strokes.

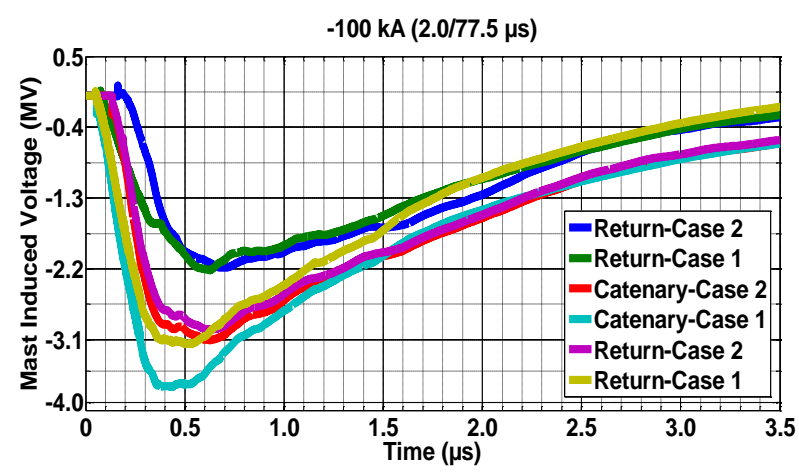

Fig. 15. Mast Induced Voltage Waveform of the $1^{\text {st }}, 2^{\text {nd }}$ and $3^{\text {rd }}$ lightning current of $-100 \mathrm{kA}(2 / 77.5 \mu \mathrm{s})$ strokes. 


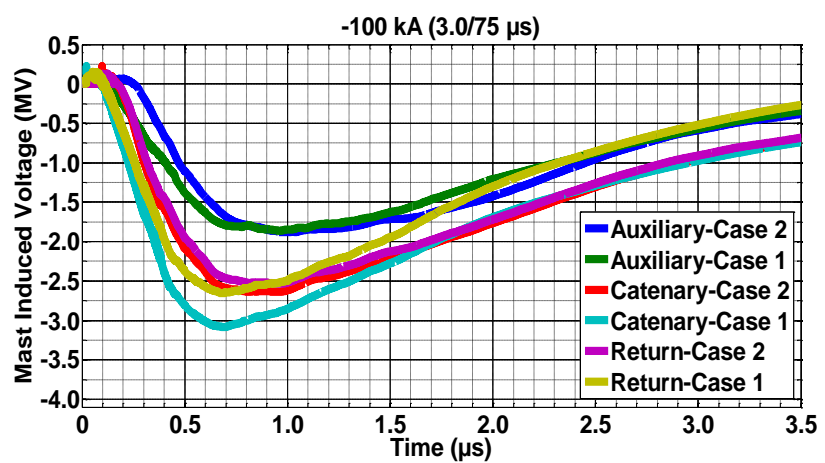

Fig. 16. Mast Induced Voltage Waveform of the $1^{\text {st }}, 2^{\text {nd }}$ and $3^{\text {rd }}$ lightning current of $-100 \mathrm{kA}(3.0 / 75 \mu \mathrm{s})$ strokes.

The magnitudes of mast induced voltages and flashover across insulators with multiple lightning strokes current for Case 1 and Case 2 are shown in Table 5 and Table 6 respectively.

Table 5. Magnitudes of Mast induced voltages (MV).

\begin{tabular}{|c|c|c|c|c|c|c|c|c|c|}
\hline \multicolumn{10}{|c|}{ Case 1} \\
\hline Lightning & \multicolumn{3}{|c|}{$-34 \mathrm{kA}$} & \multicolumn{3}{|c|}{$-50 \mathrm{kA}$} & \multicolumn{3}{|c|}{$-100 \mathrm{kA}$} \\
\hline Waveforms & $\mathrm{Ax}$ & $\mathrm{Rt}$ & $\mathrm{Ct}$ & $\mathrm{Ax}$ & $\mathrm{Rt}$ & $\mathrm{Ct}$ & $\mathrm{Ax}$ & $\mathrm{Rt}$ & $\mathrm{Ct}$ \\
\hline $1.0 / 30.2 \mu \mathrm{s}$ & 0.8 & 1.1 & 1.3 & 1.2 & 1.7 & 2.1 & 2.5 & 3.7 & 4.5 \\
\hline $1.2 / 50 \mu \mathrm{s}$ & 0.7 & 1.1 & 1.3 & 1.2 & 1.7 & 2.0 & 2.4 & 3.7 & 4.4 \\
\hline $2.0 / 77.5 \mu \mathrm{s}$ & 0.7 & 1.0 & 1.2 & 1.1 & 1.5 & 1.8 & 2.2 & 3.2 & 3.7 \\
\hline $3.0 / 75 \mu \mathrm{s}$ & 0.6 & 0.9 & 1.0 & 0.9 & 1.4 & 1.6 & 1.9 & 2.7 & 3.1 \\
\hline \multicolumn{10}{|c|}{ Case 2} \\
\hline Lightning & \multicolumn{10}{|c|}{$-34 \mathrm{kA}$} & \multicolumn{3}{|c|}{$-50 \mathrm{kA}$} & \multicolumn{7}{|c|}{$-100 \mathrm{kA}$} \\
\hline Waveforms & $\mathrm{Ax}$ & $\mathrm{Rt}$ & $\mathrm{Ct}$ & $\mathrm{Ax}$ & $\mathrm{Rt}$ & $\mathrm{Ct}$ & $\mathrm{Ax}$ & $\mathrm{Rt}$ & $\mathrm{Ct}$ \\
\hline $1.0 / 30.2 \mu \mathrm{s}$ & 0.8 & 1.1 & 1.2 & 1.2 & 1.7 & 1.8 & 2.5 & 3.5 & 3.8 \\
\hline $1.2 / 50 \mu \mathrm{s}$ & 0.8 & 1.1 & 1.2 & 1.2 & 1.6 & 1.8 & 2.4 & 3.5 & 3.8 \\
\hline $2.0 / 77.5 \mu \mathrm{s}$ & 0.7 & 1.0 & 1.0 & 1.1 & 1.5 & 1.5 & 2.2 & 3.0 & 3.1 \\
\hline $3.0 / 75 \mu \mathrm{s}$ & 0.6 & 0.8 & 0.9 & 1.0 & 1.3 & 1.4 & 1.9 & 2.5 & 2.6 \\
\hline
\end{tabular}

Table 6. Flashover across insulators.

\begin{tabular}{|c|c|c|c|c|c|c|c|c|c|}
\hline \multicolumn{10}{|c|}{ Case 1} \\
\hline Lightning & \multicolumn{3}{|c|}{$-34 \mathrm{kA}$} & \multicolumn{3}{|c|}{$-50 \mathrm{kA}$} & \multicolumn{3}{|c|}{$-100 \mathrm{kA}$} \\
\hline Waveforms & Ax & Rt & $\mathrm{Ct}$ & Ax & $\mathrm{Rt}$ & $\mathrm{Ct}$ & $A x$ & Rt & $\mathrm{Ct}$ \\
\hline $1.0 / 30.2 \mu \mathrm{s}$ & $\mathrm{s}$ & $\mathrm{s}$ & $\mathrm{s}$ & $\mathrm{s}$ & $\mathrm{s}$ & $\mathrm{s}$ & $\mathrm{s}$ & $\mathrm{s}$ & $\mathrm{s}$ \\
\hline $1.2 / 50 \mu \mathrm{s}$ & $\mathrm{s}$ & $\mathrm{s}$ & $\mathrm{s}$ & $\mathrm{s}$ & $\mathrm{s}$ & $\mathrm{s}$ & $\mathrm{s}$ & $\mathrm{s}$ & $\mathrm{s}$ \\
\hline $2.0 / 77.5 \mu \mathrm{s}$ & $\mathrm{s}$ & $\mathrm{s}$ & $\mathrm{s}$ & $\mathrm{s}$ & $\mathrm{s}$ & $\mathrm{s}$ & $\mathrm{s}$ & $\mathrm{s}$ & $\mathrm{s}$ \\
\hline $3.0 / 75 \mu \mathrm{s}$ & s & $\mathrm{s}$ & $\mathrm{s}$ & $\mathrm{s}$ & $\mathrm{s}$ & s & $\mathrm{s}$ & $\mathrm{s}$ & s \\
\hline \multicolumn{10}{|c|}{ Case 2} \\
\hline Lightning & \multicolumn{3}{|c|}{$-34 \mathrm{kA}$} & \multicolumn{3}{|c|}{$-50 \mathrm{kA}$} & \multicolumn{3}{|c|}{$-100 \mathrm{kA}$} \\
\hline Waveforms & $A x$ & Rt & $\mathrm{Ct}$ & Ax & Rt & $\mathrm{Ct}$ & Ax & Rt & $\mathrm{Ct}$ \\
\hline $1.0 / 30.2 \mu \mathrm{s}$ & s & $\mathrm{s}$ & $\mathrm{s}$ & $\mathrm{s}$ & $\mathrm{s}$ & s & $\mathrm{s}$ & $\mathrm{s}$ & $\mathrm{s}$ \\
\hline $1.2 / 50 \mu \mathrm{s}$ & $\mathrm{s}$ & $\mathrm{s}$ & $\mathrm{s}$ & $\mathrm{s}$ & $\mathrm{s}$ & $\mathrm{s}$ & $\mathrm{s}$ & $\mathrm{s}$ & $\mathrm{s}$ \\
\hline $2.0 / 77.5 \mu \mathrm{s}$ & $\mathrm{s}$ & $\mathrm{s}$ & $\mathrm{s}$ & $\mathrm{s}$ & $\mathrm{s}$ & $\mathrm{s}$ & $\mathrm{s}$ & $\mathrm{s}$ & $\mathrm{s}$ \\
\hline $3.0 / 75 \mu \mathrm{s}$ & $\mathrm{s}$ & $\mathrm{s}$ & $\mathrm{s}$ & $\mathrm{s}$ & $\mathrm{s}$ & $\mathrm{s}$ & $\mathrm{s}$ & $\mathrm{s}$ & $\mathrm{s}$ \\
\hline
\end{tabular}

Key: S - flashover, Ax - Auxiliary line, Rt - Return line and $\mathrm{Ct}$ - Catenary line

\section{Conclusion}

This paper has studied the characteristics of transient current in term of its magnitude, front times and tail times of negative Multiple lightning strokes and its behavior when the pantograph is at the Mast ( $4^{\text {th }}$ Mast) and at the mid-span of Masts ( $3^{\text {rd }}$ and $4^{\text {th }}$ Masts). The analysis was made for the flashover voltage across insulators of a $2 \times 25$ $\mathrm{kV}, 50 \mathrm{~Hz}$ AC Catenary Contact system used in Thailand. It was seen that shorter front time, resulted into higher mast induced voltage. Similarly, a higher magnitude of Multiple lightning strokes, induced higher voltages across mast insulators for case 1 and case 2. The Flashover occurred for all waveforms and current magnitude from $-34 \mathrm{kA}$ to -100 kA when pantograph was at the Mast and at the mid-span of Masts. Critical flashover voltage was found in case 1 compared to case 2. Therefore, short front time and high magnitude of negative multiple lightning strokes are key parameters which may be considered in lightning protection.

\section{Acknowledgment}

This work was supported by Laboratory of High Voltage Insulation Technologies of Suranaree University of Technology, Thailand.

\section{References}

(1) Sokratis Pastromas, Alkistis Papamikou, Georgios Peppas, and Eleftheria Pyrgioti : "Investigation of grounding resistance effect on the MV grid of Hellenic electromotive railway during lightning strikes", $33^{\text {rd }}$ International Conference on Lightning Protection, pp. 1-7, 2016.

(2) Friedrich Kiessling, Rainer Puschmann, Axel Schmieder, and Egid Schneider : "Contact Lines for Electrical Railways: Planning - Design Implementation - Maintenance", $2^{\text {nd }}$ edition, Siemens Aktiengesellschaft, Berlin and Murnich, pp. 123-876, 2009.

(3) Tomasz Chmielewski, and Andrzej Dziadkowiec : "Simulations of Fast Transients in typical $25 \mathrm{kV}$ a.c. railway power supply system", Seminarium ZASTOSOWANIE KOMPUTERÓW W NAUCE I 
TECHNICE 2013, Gdańsk, Polska, Vol. 23, No. 36, pp. 43-46, 2013.

(4) R. Bhattarai, R. Rashedin, S. Venkatesan, A. Haddad, H. Griffiths, and N. Harid : "Lightning performance of $275 \mathrm{kV}$ Transmission lines", 43 ${ }^{\text {rd }}$ International Universities Power Engineering Conference, pp. 1-5, 2008.

(5) IEEE Std 1100 : "IEEE Recommended Practice for Powering and Grounding Electronic Equipment", IEEE Standards, 1999.

(6) IEEE Std 1313.2 : "IEEE Guide for the Application of Insulation Coordination”, IEEE Standards, 1999.

(7) Pantelis N. Mikropoulos and Thomas E. Tsovilis : "Estimation of the shielding performance of overhead transmission lines: the effects of lightning attachment model and lightning crest current distribution", IEEE Transactions on Dielectrics and Electrical Insulation, Vol. 19, No. 6, pp. 2155-2164, 2012.

(8) Farid Achouri, Imed Achouri, and Mabrouk Khamliche : "Protection of $25 \mathrm{kV}$ Electrified Railway System", 4th International Conference on Electrical Engineering(ICEE), pp. 1-6, 2015.

(9) Yuxin Yang, and Youpeng Zhang : "Research on Lightning Protection Simulation of High-speed Railway Catenary Based on ATP-EMTP", Journal of information \& Computation Science, Vol 12, No. 4, pp. 1511-1521, 2015.

(10) Liu, J., and Liu, M.G. "Improved electro-geometric model for estimating lightning outage rate of catenary," IET Electrical Systems in Transportation, Vol. 2, pp. 1-8, 2012.

(11) Avishkar Vijay Wanjari : "Effect of Lightning on the Electrified Transmission Railway System", International Journal of Advance Research in Electrical, Electronics and Instrumentation Engineering, Vol. 3, Issue. 7, pp. 10663-10671, 2014.

(12)Ziya Mazloom : "Multi-conductor transmission line model for electrified railways: A method for responses of lumped devices", Doctoral Thesis, KTH Electrical Engineering University, Stockholm, Sweden, pp. 59-72, 2010.

(13) Amedeo Andreotti, Umberto De Martinis, Antonio Pierno1, and Vladimir A. Rakov : "A New Tool for Lightning Induced Voltage Calculations: CiLIV", General Assembly and Scientific Symposium (URSI GASS), 2014 XXXIth URSI, pp. 1-4, 2014.

(14)Boonruang Marungsri, Suphachai Boonpoke, Anucha Rawangpai, Anant Oonsivilai, and Chanin
Kritayakornupong : "Study of Tower Grounding Resistance Effected Back Flashover to $500 \mathrm{kV}$ Transmission Line in Thailand by using ATP/EMTP”, International Journal of Electrical, Computer, Energetic, Electronic and Communication, Vol. 2, No. 6, pp. 1061-1068, 2008.

(15) Michael A. Omidiora, and Matti Lehtonen : "Performance of Surge Arrester to Multiple Lightning Strokes on Nearby Distribution Transformer", Proceedings of the 7th WSEAS International Conference on Power Systems, Beijing, China, pp. 59-65, 2007.

(16)Juan A. Martínez-Velasco, and Ferley Castro-Aranda : "EMTP Implementation of a Monte Carlo Method for Lightning Performance Analysis of Transmission Lines", Ingeniare. Revista chilena de ingeniería, Vol. 16, No. 2, pp. 169-180, 2008.

(17) Michael A. Omidiora, and Matti Lehtonen : "Simulation of Combined Shield Wire and MOV Protection on Distribution Lines in Severe Lightning Areas", Proceedings of the World Congress on Engineering and Computer Science, 2007.

(18) Doeg Rodriguez-Sanabria, Carlos Ramos-Robles, and Lionel R. Orama-Exclusa : "Lightning and Lightning Arrester Simulation in Electrical Power Distribution Systems", pp. 1-9, 2011.

(19) IEC 60850 : "Railway Applications - Supply Voltages of Traction Systems", International Electrotechnical Commission standard, 2014.

(20)Zhang Yongji, Sima Wenxia, and Zhang Zhijin : "Summary of the study of tower models for lightning protection analysis", High Voltage Engineering, pp. 93-97, 2006.

(21) Alan Župan, Ana Tomasović Teklić, and Božidar Filipović-Grčić : "Modeling of 25 kV Electric Railway System for Power Quality Studies", EuroCon 2013.Zagreb, Croatia, pp. 844-849, 2013.

(22) Mustafa KaragÖz : "Analysis of the Pantograph Arcing and Its Effect of the Railway Vehicle", Master Degree Thesis, Middle East Technical University. pp. 59-72, 2014.

(23) Ali F. Imece, Daniel W. Durbak, Hamid Elahi, Sharma Kolluri, Andre Lux, Doug Mader, Thomas E. McDemott, Atef Morched, Abdul M. Mousa, Ramasamy Natarajan, Luis Rugeles, and Eva Tarasiewicz : "Modeling Guidelines for Fast Front Transients", IEEE Transactions on Power Delivery, Vol. 11, No. 1, pp. 493-506, 1996. 